\title{
PHYTOCHEMICAL, PROXIMATE AND MINERAL ANALYSIS OF DIFFERENT PARTS OF SENNA ALATA LINN
}

\section{Okeke U. Clement, Okeke N. Philomena*, Orji N. May, Mbaukwu A. Onyinye and Iroka F. Chisom}

Department of Botany, Nnamdi Azikiwe University, Awka. P. M. B 5025 Anambra State. Nigeria

*Corresponding author: np.okeke@unizik.edu.ng; okekeprisca36@gmailcom

Cite this article:

Okeke U.C., Okeke N.P., Orji N.M., Mbaukwu A.O., Iroka F.C. (2021), Phytochemical, Proximate and Mineral Analysis of Different Parts of Senna Alata Linn. Research Journal of Biotechnology and Life Science 1(1), 18-28. DOI: 10.52589/RJBLSLLHPMRF6.

\section{Manuscript History}

Received: 30 June 2021

Accepted: 28 July 2021

Published: 8 Oct 2021

Copyright $\odot 2020$ The Author(s). This is an Open Access article distributed under the terms of Creative Commons AttributionNonCommercial-NoDerivatives 4.0 International (CC BY-NC-ND 4.0 ), which permits anyone to share, use, reproduce and redistribute in any medium, provided the original author and source are credited.
ABSTRACT: This study was carried out to determine the phytochemical and proximate composition of the flowers, leaves, stem and root of Senna alata. The phytochemical analysis result

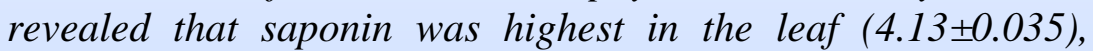
flavonoid was higher in the stem (6.63 \pm 0.064$)$ while anthraquinone was highest in the root $(4.52 \pm 0.438)$. The result of the proximate analysis showed that carbohydrate was higher in the leaf (33.81 \pm 0.827$)$, root $(50.52 \pm 1.945)$ and flower (55.67 \pm 0.021$)$. The result of the mineral composition showed that the leaf, root, flower and stem extract of $S$. alata were higher in potassium $(779.01 \pm 0.276,556.39 \pm 0.198,1121.85 \pm 0.141$, and $246.29 \pm 0.042)$. The results obtained from this research revealed that the leaves, roots, flowers and stem of Senna alata Linn were rich in crude fibre, crude protein, carbohydrate, potassium, magnesium, iron and calcium. That is, well-processed parts of Senna alata may improve the health status of livestock.

KEYWORDS: Phytochemical, Proximate, Mineral, Senna alata 


\section{INTRODUCTION}

Man since immemorial time has been using herbs/plant produce as medicine for developing immunity or resistance against cold, joint pains, fevers and so on. Scientific data in a good number of medicine plants investigated has been well documented. However, only a few drugs of plant origin could reach clinical use and the National formulator could not adopt even a dozen of plants for medicine. For this reason, a special effort is needed in the development of herbal drugs having therapeutic utility (Jude et al., 2007). Medicinal principles are present in different parts of plants like the root, stem, bark, heartwood, leaf, flower, fruits and plant exudates. These medicinal principles are separated by different processes; with the most common being extraction (Burkill, 2002).

Senna alata is a pan-tropical ornamental shrub belonging to the Caesalpinaceae family. It is commonly known as ringworm plant and is widely distributed from tropical America to India (Abdulwaliyu et al., 2013). The leaves are known to possess analgesic, antimicrobial, antitumor and antidiabetic properties (Somchit et al., 2003). It is locally used in Nigeria in the treatment of several infections such as ringworm and parasitic skin diseases. The leaves have been used as abortifacients to hasten labour (Yakubu et al., 2010). The leaves are reported in the treatment of convulsion, gonorrhoea, heart failure, abdominal pains, oedema and as purgative (Ogunti and Elujoba, 2009). The flower is locally credited by Makinde et al., (2007) for the treatment of syphilis and diabetes. The Phytochemical contents have been studied for their therapeutic potency but under-nutrition is the basic concern for developing countries. However, the nutritional information is skimpy.

\section{MATERIALS AND METHODS}

Plant collection: S. alata plant was collected from the environment of Management Sciences, Nnamdi Azikiwe University Awka in Awka L. G. A., Anambra State, Nigeria. The name was authenticated by Prof. C. U. Okeke from the Department of Botany, Unizik.

Plant preparation: The plant parts were examined for diseases and extraneous materials were removed before being air-dried for 21 days. The dried plant parts were separately grounded into pestle, mortar and Panasonic blender.

Phytochemical screening: The phytochemical screening was carried out using the method of Usunobun and Ewaen (2014) on the samples to determine the presence or absence of phytochemicals of interest as Saponin, Flavonoid, Tannin, Phenols, Alkaloid, Steroid, Terpenoids, Hydrogen cyanide and Cyanogenic glycosides.

\section{Qualitative Determination of Phytochemical Contents}

Test for Saponin $2 \mathrm{~g}$ of each sample was boiled in $20 \mathrm{ml}$ of distilled water using a water bath. $10 \mathrm{ml}$ of the filtrate was mixed with $5 \mathrm{ml}$ of distilled water in a tube. The mixture was shaken vigorously. The presence of a steady froth indicates the presence of saponin.

Test for Flavonoid $5 \mathrm{ml}$ of $10 \%$ dilute ammonia was added to a portion of the methanol filtrate of each plant sample, this was followed by the addition of $\mathrm{H}_{2} \mathrm{SO}_{4}$. A yellow colouration indicated the presence of flavonoids. 
Test for Alkaloid $2 \mathrm{ml}$ of each sample was warmed with $2 \% \mathrm{H}_{2} \mathrm{SO}_{4}$ for 2 mins. then filtered, a few drops of Meyer's reagent was added. The formation of creamy white precipitate indicated the presence of alkaloids.

Test for Tannin Each of the plant sample was dissolved in $5 \mathrm{ml}$ of distilled water. A few drops of $5 \%$ ferric chloride was added to the solution. The formation of dark green colour indicates the presence of tannin.

Test for Steroids 50mg of each sample was dissolved in $2 \mathrm{ml}$ of acetic anhydride. Few drops of conc sulphuric acid were added slowly along the sides of the test tubes. An array of colour changes indicates the presence of steroids

Test foe Terpenoids $0.5 \mathrm{~g}$ of each sample was dissolved in $1 \mathrm{ml}$ of chloroform, acetic anhydride and $2 \mathrm{ml}$ of conc $\mathrm{H}_{2} \mathrm{SO}_{4}$. The formation of reddish-violet colour indicates the presence of terpenoids

Test for Hydrogen cyanide This was done using a spot paper test. Few drops of toluene solution were added to $1 \mathrm{ml}$ of each sample. A change of the yellow colour of the paper to brick red indicates the presence of Hydrogen cyanide

Test for Phenol $1 \mathrm{ml}$ of $10 \%$ ferric chloride was added to $1 \mathrm{ml}$ of each extract. The formation of a greenish-brown or black precipitate is known to be positive for a phenolic nucleus

Test for Cyanogenic glycosides Keller Killani test was to test for the presence of glycosides in different samples of $S$. alata. $1 \mathrm{ml}$ of each sample was dissolved in $2 \mathrm{ml}$ of glacial acetic acid containing a drop of ferric chloride solution. This was underlaid with $1 \mathrm{ml}$ of conc sulphuric acid. A brown ring obtained showed the presence of deoxy sugar characteristics of cardenolides

\section{Quantitative determination of phytochemical contents}

Determination of Alkaloid This was done by the alkaline ppt gravimetric method described by Harborne (1973). $5 \mathrm{~g}$ of each sample was dispersed into $50 \mathrm{ml}$ of $10 \%$ acetic acid sol in ethanol. The mixture was shaken and allowed to stand at room temp for $4 \mathrm{hrs}$. It was filtered using Whatman No. 42 grade of the filter. The filtrate was concentrated to a quarter of its original volume by evaporation over a steam bath. The alkaloid in the extract was precipitated by dropwise addition of $\mathrm{NH}_{4} \mathrm{OH}$ until full turbidity was obtained. The alkaloid ppt was recovered using a weighed filter paper, and washed with $1 \%$ ammonia solution, dried in the oven at $80^{\circ} \mathrm{C}$ for an hour. It was cooled in a desiccator and reweighed. By weight difference, the weight of the alkaloid was determined and expressed as a percentage of the sample analyzed, using the formula alkaloid $\%=\mathrm{W}_{2}-\mathrm{W}_{1} * 100 / 1$. Where; $\mathrm{W}_{1}=$ weight of the sample. $\mathrm{W}_{2}=$ weight of empty filter paper

Determination of Flavonoid This was done by the method of Boham and Kocipai (1994). 10g of each sample was extracted repeatedly into $100 \mathrm{ml}$ of $80 \%$ aqueous methanol at room temperature. The whole solution was filtered, the filtrate transferred into a crucible and evaporated to dryness over a water bath and weighed. The weight was calculated as Flavonoid $\%=\mathrm{W}_{2}-\mathrm{W}_{1} /$ Weight of the sample $\mathrm{x} 100 / 1$. Where $\mathrm{W}_{1}=$ weight of empty filter paper. $\mathrm{W}_{2}=$ weight of paper + flavonoid precipitate 
Determination of Phenol The Follins method described by Pearson (1976) was used to determine the presence of Phenol. $0.2 \mathrm{~g}$ of each sample was dispersed in $10 \mathrm{ml}$ of methanol and shaken. It stood for 30min at room temperature and was then filtered using Whatman filter paper. $1 \mathrm{ml}$ of each extract was placed in a test tube and was added $1 \mathrm{ml}$ of Follin's reagent with $5 \mathrm{ml}$ of distilled water. It was allowed at room temperature for 3-4 hrs so the colour can form. The absorbance of the developed colour was measured at a $760 \mathrm{~nm}$ wavelength. The phenol content was calculated thus: \%Phenol $=100 / \mathrm{W} * \mathrm{Au} / \mathrm{As} * \mathrm{C} / 100 * \mathrm{Vf} / \mathrm{Va} * \mathrm{D}$. Where $\mathrm{W}=$ weight of sample analyzed. $\mathrm{Au}=$ absorbance of the test tube. As= absorbance of standard solution. $\mathrm{C}=$ conc. standard $(\mathrm{mg} / \mathrm{ml}) . \mathrm{Vf}=$ total filtrate volume. $\mathrm{Va}=$ volume of filtrate analyzed. $\mathrm{D}=$ dilution factor

Determination of Saponin Double solvent extraction gravimetric method was followed as described by Harborne (1973). $5 \mathrm{~g}$ of the powdered sample was weighed out and mixed with $50 \mathrm{ml}$ of $20 \%$ aqueous ethanol solution. The mixture was heated on a water bath for $90 \mathrm{mins}$ at $55^{\circ} \mathrm{C}$. it was filtered and the residue re-extracted with $50 \mathrm{ml}$ of $20 \%$ ethanol, both extracts were combined together. The combined extracts were reduced to $40 \mathrm{ml}$ over a water bath at $90^{\circ} \mathrm{C}$. The concentration was transferred into a 250 separating funnel where $40 \mathrm{ml}$ of diethyl ether was added and shaken vigorously. Separation was by partition during which the aqueous layer was recovered and the ether layer discarded. Re-extraction by partition was done repeatedly until the aqueous layer became clear in colour. The saponins were extracted with $60 \mathrm{ml}$ of normal butanol. The combined n-butanol extract was washed with $5 \%$ aqueous $\mathrm{NaCl}$ sol. and was evaporated to dryness in a pre-weighed evaporating dish. It was dried at $60^{\circ} \mathrm{C}$ in the oven and weighed. The experiment was repeated twice so as to get an average. The saponin content was determined and expressed as a percentage of the weight analysed. Given by the formula saponin $\%=\mathrm{W}_{2}-\mathrm{W}_{1} * 100 / 1$. Where; $\mathrm{W}_{1}=$ weight of the sample. $\mathrm{W}_{2}=$ weight empty of filter paper

Determination of Steroid This was determined using the method described by Okeke and Elekwa (2003). A $0.5 \mathrm{~g}$ weight of each sample was dispersed in $100 \mathrm{ml}$ freshly distilled water and homogenized in a laboratory blender which is then filtered and the filtrate eluted with normal $\mathrm{NH}_{4} \mathrm{OH}$ solution at $\mathrm{pH} 9.2 \mathrm{ml}$ of the eluted sample was put in a test tube and mixed with $2 \mathrm{ml}$ of chloroform, $2 \mathrm{ml}$ of acetic anhydride and 2 drops of conc. $\mathrm{H}_{2} \mathrm{SO}_{4}$ was cautiously added to the mixture. Standard steroid solution was prepared and treated. The absorbance of standard and prepared samples were measured in a spectrophotometer at $420 \mathrm{~nm}$ wavelength, with the reagent blank at zero. The experiment was repeated to get an average. Steroid content was calculated as steroid $\%=100 / \mathrm{W} \times \mathrm{Au} / \mathrm{As} \times \mathrm{C} / 1000 \times \mathrm{V}_{\mathrm{f}} / \mathrm{V}_{\mathrm{a}}$. Where $\mathrm{W}=$ weight of sample analysed. $\mathrm{Au}=$ absorbance of the test sample. As= absorbance of standard solution in $\mathrm{mg} / \mathrm{ml}$. $\mathrm{V}_{\mathrm{f}}=$ total volume of extract. $\mathrm{V}_{\mathrm{a}}=$ volume of extract analyzed

Determination of Tannin The tannin content was determined using the Folin-Dennis spectrophotometric method described by Pearson (1976). About 1g of the sample was dispersed in $10 \mathrm{ml}$ of distilled water and was shaken. This was left to stand for $30 \mathrm{mins}$ at room temperature while being shaken every $5 \mathrm{mins}$. It was then centrifuged and the extract got. $2.5 \mathrm{ml}$ of the supernatant was dispersed into a $50 \mathrm{ml}$ volumetric flask. Similarly, $2.5 \mathrm{ml}$ of the standard tannic acid solution was dispersed into a separate $50 \mathrm{ml}$ flask. $1 \mathrm{ml}$ of folic-denis reagent was measured into each flask, followed by $2.5 \mathrm{ml}$ of saturated $\mathrm{Na}_{2} \mathrm{CO}_{3}$ solution. The mixture was diluted and incubated for $90 \mathrm{mins}$ at room temperature. The absorbance was measured at $250 \mathrm{~nm}$ in a UV VIS spectrophotometer, readings were taken with the reagent blank at zero. The tannin content was given as $\operatorname{tannin} \%=100 / \mathrm{W} \times \mathrm{A}_{\mathrm{n}} / \mathrm{A}_{\mathrm{s}} \times \mathrm{V}_{\mathrm{f}} / \mathrm{V}_{\mathrm{a}}$. Where $\mathrm{A}_{\mathrm{n}}=$ absorbance of the test sample. $\mathrm{A}_{\mathrm{s}}=$ 
absorbance of standard solution. $\mathrm{C}=$ concentration of the standard solution. $\mathrm{W}=$ weight of sample used. $\mathrm{V}_{\mathrm{f}}=$ total volume of extract. $\mathrm{V}_{\mathrm{a}}=$ volume of extract analyzed.

Determination of Cyanogenic glycosides This was done using Onwuka (2005). $5 \mathrm{~g}$ of each sample was dissolved in $50 \mathrm{ml}$ of distilled water in a conical flask which was left overnight and filtered the next day. $4 \mathrm{ml}$ of alkaline picrate was added to $1 \mathrm{ml}$ of the sample filtrate in a corked test tube and boiled in a water bath for $5 \mathrm{~min}$. After colour development, the filtrate was read in a spectrophotometer at $490 \mathrm{~nm}$. Also, the absorbance of the blank containing $1 \mathrm{ml}$ of distilled water and $4 \mathrm{ml}$ of alkaline solution. Then the cyanide content was extrapolated using a standard curve.

\section{Proximate Analysis}

Determination of Moisture content The moisture content was determined by the gravimetric method as described by Bradley (2003). $5 \mathrm{~g}$ of the fresh sample was put in a weighed moisture can and dried in the oven at $105^{\circ} \mathrm{C}$ for 3 hours, cooled in a desiccator and weighed. The weight was recorded and the sample was returned to the oven for further drying. The process was repeated until a constant weight was obtained. By weight difference, the moisture loss was determined and expressed as a percentage of the sample weight analysed. \%Moisture $=\left(\mathrm{W}_{2}-\right.$ $\left.\mathrm{W}_{3}\right) /\left(\mathrm{W}_{2}-\mathrm{W}_{1}\right)^{*} 100 / 1$. Where $\mathrm{W}_{1}=$ weight of empty moisture can. $\mathrm{W}_{2}=$ weight of moisture can + sample before drying. $\mathrm{W}_{3}=$ weight of moisture can + sample after drying to constant weight.

Determination of Ash content The furnace incineration gravimetric method (Harbors and Nielson, 2003) was used. 5g each of the processed samples were measured into a previously weighed porcelain crucible. The sample was burnt to ashes in a muffle furnace at $550^{\circ} \mathrm{C}$. It was then in a desiccator and weighed. The weight of ash obtained was calculated by difference and expressed as a percentage of the sample analysed: $\& a s h=\left(\mathrm{W}_{2}-\mathrm{W}_{1}\right) / \mathrm{W}^{*} 100 / 1$. Where $\mathrm{W}=$ weight of the sample. $\mathrm{W}_{1}=$ weight of empty crucible. $\mathrm{W}_{2}=$ weight of crucible + ash.

Determination of Crude fibre The Weeden method (Bemillar, 2003) was employed. 5g of the defatted sample was boiled in $200 \mathrm{ml}$ of $1.25 \% \mathrm{H}_{2} \mathrm{SO}_{4}$ solution under reflux for $30 \mathrm{~min}$. the sample was washed with several portions of hot water using a two-fold muslin cloth to trap the particle, then transferred quantitatively back into the flask. $200 \mathrm{ml}$ of $1.25 \% \mathrm{NaOH}$ sol was added to it. Again, the sample was boiled for 30min and washed with hot water. It was then transferred to a weighed porcelain crucible and dried in the oven at $105^{\circ} \mathrm{C}$ for an hour, cooled in a desiccator and reweighed. The loss in weight after incineration was used to determine the crude fibre content and expressed as a percentage of the weight of the sample: \%crude fibre= $\left(\mathrm{W}_{2}-\mathrm{W}_{3}\right) / \mathrm{W}_{1} * 100 / 1$. Where $\mathrm{W}_{1}=$ weight of the sample. $\mathrm{W}_{2}=$ weight of crucible + sample after drying. $\mathrm{W}_{3}=$ weight of crucible + sample (after ashing).

Determination of Crude fat Soxhlet extraction method was used as described by Min and Boff (2003). $5 \mathrm{~g}$ of each sample was wrapped with a weighed porous paper (Whatman filter paper No. 40). The wrapped samples were put in a soxhlet reflux flask. The flak was mounted into an oil extraction flask containing 300mlbof petroleum ether and boiled at $60^{\circ} \mathrm{C}$ boiling points. The vaporized solvent condensed into the reflux flask and siphons over when it fills up carrying extracted oil down the boiling flask. This cycle was allowed to go on uninterrupted for about $4 \mathrm{hrs}$. The defeated samples were brought out with the aid of forceps and further dried in the oven at $100^{\circ} \mathrm{C}$ for $1 \mathrm{hr}$, cooled in a desiccator and weighed. The fat content was determined by the weight difference of each sample and expressed as a percentage of each 
weight sample as $\%$ fat $=\left(\mathrm{W}_{2}-\mathrm{W}_{3}\right) /\left(\mathrm{W}_{2}-\mathrm{W}_{1}\right) * 100 / 1$. Where $\mathrm{W}_{1}=$ weight of empty filtered paper. $\mathrm{W}_{2}=$ weight of paper + sample before defatting. $\mathrm{W}_{3}=$ weight of paper + sample after defatting and drying.

Determination of Crude protein The protein content of each of the samples was determined by the Kjeldahl method as described by Chang (2003). The total was determined and multiplied by the factor 6.38 to obtain the protein content. $1 \mathrm{ml}$ of each sample was mixed with $10 \mathrm{ml}$ of conc. sulphuric acid in a Kjeldahl digestion flask. A tablet of selenium catalyst was added to it and the mixture was digested by heating in a fume cupboard until a clear solution was obtained. Each of the digests was carefully transferred to a $100 \mathrm{ml}$ volumetric flask and made up to the mark with distilled water. A $10 \mathrm{ml}$ of each digest was mixed with an equal volume of $45 \%$ $\mathrm{NaOH}$ sol in a Kjeldahl distilling unit. The mixture was distilled and the distillate was collected into $10 \mathrm{ml}$ of $4 \%$ buric acid containing 3 drops of mixed indicator (bromocressol, green and methyl red). A total of 50mls distillate was collected and titrated against $0.02 \mathrm{~N} \mathrm{H}_{2} \mathrm{SO}_{4}$ from green to deep red endpoint. A reagent blank was also digested, distilled and titrated. The $\mathrm{N}_{2}$ and protein content was calculated as $\mathrm{N}_{2} \%=100 / \mathrm{W} *(\mathrm{~N} * 14) / 1000 * \mathrm{~V}_{\mathrm{f}} / \mathrm{V}_{\mathrm{a}} * \mathrm{~T}-\mathrm{B}$. Where: $\mathrm{N}=$ normality of titrant $\left(\mathrm{H}_{2} \mathrm{SO}_{4}\right) . \mathrm{V}_{\mathrm{f}}=$ total volume of the digest. $\mathrm{V}_{\mathrm{a}}=$ volume of digest distilled. $\mathrm{T}=$ titre volume of sample. $\mathrm{B}=$ titre value of a reagent blank.

Determination of Carbohydrate This was done by elimination using the arithmetic difference method as described by Pearson (1976) and James (1995). CHO\% $\left(\mathrm{N}_{2}\right.$ free extracted) $=100-$ $\%(\mathrm{~A}+\mathrm{B}+\mathrm{C}+\mathrm{D})$. Where: $\mathrm{A}=$ protein. $\mathrm{B}=$ fat. $\mathrm{C}=$ ash. $\mathrm{D}=$ fibre

\section{Mineral Analysis}

The mineral content of the samples was determined by the dry ash acid extraction method described by Capenter and Hendricks (2003). $5 \mathrm{~g}$ of each sample was burnt to ashes in a muffle furnace at $50^{\circ} \mathrm{C}$. The resulting ash was dissolved in $10 \mathrm{ml}$ of $2 \mathrm{M} \mathrm{HCl}$ sol and diluted to $100 \mathrm{ml}$ in a flask using distilled water and filtered. The filtrate was used for the mineral analysis.

Determination of Calcium and Magnesium This was carried out by versanate EDTA complexometric titrimetric method. $20 \mathrm{ml}$ portion of each extract was dispersed into a conical flask and treated with inches of masking agents (hydroxylamine hydrochloride, sodium cyanide and sodium-potassium ferrocyanide). The flask was shaken and the mixture dissolved. $20 \mathrm{ml}$ of ammonia was added to it to raise the $\mathrm{p}^{\mathrm{H}}$ to 10.00 (a point at which both calcium and magnesium form complexes with EDTA). The mixture was titrated against 0.02N EDTA solution using Erochiome Black $\mathrm{T}$ as an indicator. A reagent black was titrated and titration in each case was done from deep red to a permanent blue endpoint. The titration value represents both calcium and magnesium ions in the test sample. A repeat titration was done, $\mathrm{Ca}^{2+}$ alone in the test samples, $10 \% \mathrm{NaOH}$ was used in place of the ammonium buffer and sole chrome dark blue indicator in place of Erichrome Black T. At $\mathrm{pH}$ of $12.0 \mathrm{Ca}^{2+}$ complexes with EDTA. \% Ca and $\mathrm{Mg}=(100 / \mathrm{W}) * \mathrm{EW}^{*} \mathrm{~N} *(\mathrm{Vf} / \mathrm{Va}) * \mathrm{~T}-\mathrm{B}$. Where $\mathrm{W}=$ weight of the sample analysed. $\mathrm{EW}=$ Equivalent weight. $\mathrm{N}=$ Normality of EDTA. $\mathrm{Vf}=$ total volume of extract. $\mathrm{Va}=$ volume of extract titrated. $\mathrm{T}=$ titre value of sample. $\mathrm{B}=$ titre value of blank.

Determination of Sodium and Potassium Flame photometry was used to determine the concentration of $\mathrm{K}$ and $\mathrm{Na}$. The photometer was set up, switched on and allowed to stay for about 10min. The gas and air inlets were opened and the start knob was adjusted to a nonluminous flame. Meanwhile, standard $\mathrm{K}$ and $\mathrm{Na}$ sol were prepared separately and each diluted 
to conc 2, 4, 6, 8 and 10ppm. The appropriate conc filter was selected for $\mathrm{K}$ and $\mathrm{Na}$. the highest conc standard sol was aspirated and its emission intensity adjusted to 100units. Therefore, starting with the least conc. (2ppm), each standard sol was aspirated and caused to spray over the non-luminous butane gas flame. The emission intensity read directly on the instrument and the readings were recorded. Then the samples digests were also aspirated and had their reading taken. The emission intensities of the standards were plotted against their conc to obtain a standard curve (calibration graph) for each element. Subsequently, the optical density emission recorded from each of the samples was matched against those in the curve to extrapolate the quantity of each potassium and sodium ion in the sample. The experiment was repeated three times to get a mean concentration. The conc of the test minerals were calculated as follows: $\% \mathrm{~K}$ or $\mathrm{Na}(\mathrm{mg} / 100 \mathrm{~g})=(100 / \mathrm{W}) *(1 / 1000) * \mathrm{X}^{*}(\mathrm{Vf} / \mathrm{Va}) * \mathrm{D}$. where $\mathrm{W}=$ weight of sample used. $\mathrm{X}=$ concentration $(\mathrm{ppm})$ from curve. $\mathrm{Vf}=$ total volume of extract. $\mathrm{Va}=$ volume of extract (digest) flamed. $\mathrm{D}=$ dilution factor where applicable.

Determination of Phosphorus This was done by a process described by James (1995). $1 \mathrm{ml}$ of each sample was dispensed into a test tube. Similarly, the volume of standard solution, as well as water, were put in a test tube to serve as a standard and blank respectively, the content of each tube was mixed with an equal volume of the vanado-molybdate colour reagent. They were left to stand for 15 mins at room temperature before their absorbance was measured in an electronic spectrophotometer at a wavelength of $420 \mathrm{~nm}$. Measurements were taken with the blank at zero. Phosphorus content was given by the formula: $\mathrm{mg} / 100 \mathrm{~g}=(100 / \mathrm{w}) \mathrm{x}(\mathrm{Au} / \mathrm{As}) \mathrm{x}$ $\mathrm{C} \times(\mathrm{Vf} / \mathrm{Va})$. Where; $\mathrm{w}=$ weight of sample analysed. $\mathrm{Au}=$ Absorbance of test sample. As= Absorbance of standard solution

\section{Statistical Analysis}

All data from the analysis of the flower, leaves, stem, and root samples were subjected to a statistical analysis system (SSA, 2000) software package. ANOVA was done and mean of separation using Fisher Least Significant Difference (LSD).

\section{RESULTS}

The result of the qualitative phytochemical screening of the leaf, root, flower and stem of Senna alata is shown below:

Table 1: Qualitative phytochemical constituent of different parts of Senna alata

\begin{tabular}{llllllll}
\hline Extract & Alkaloid & Flavonoid & Saponin & Phenol & Tannin & Anthraquinone & Steroid \\
\hline Leaf & +++ & + & +++ & - & ++ & ++ & + \\
Root & ++ & ++ & ++ & - & + & +++ & + \\
Flower & ++ & ++ & +++ & - & + & ++ & + \\
Stem & + & +++ & + & - & - & + & + \\
\hline
\end{tabular}

$+++=$ abundantly present; $++=$ present; $+=$ slightly present 
The above result shows that saponin was abundantly present in the leaf and flower extract of $S$. alata. Flavonoid was also abundant in the stem, while anthraquinone was abundant in the root. The phytochemical constituent was present in all different parts of Senna alata except tannin.

Table 2: Quantitative phytochemical constituent of different parts of Senna alata

\begin{tabular}{llllllll}
\hline Extract & Alkaloid & Flavonoid & Saponin & Phenol & Tannin & $\begin{array}{l}\text { Anthraq } \\
\text { uinone }\end{array}$ & Steroid \\
\hline Leaf & $4.08 \pm 0.028$ & $1.49 \pm 0.001$ & $4.31 \pm 0.035$ & $0.38 \pm 0.021$ & $1.55 \pm 0.007$ & $2.75 \pm 0.113$ & $0.67 \pm 0.021$ \\
Root & $1.64 \pm 0.021$ & $1.91 \pm 0.014$ & $2.74 \pm 0.014$ & $0.27 \pm 0.021$ & $1.47 \pm 0.021$ & $4.52 \pm 0.438$ & $0.54 \pm 0.021$ \\
Flower & $2.73 \pm 0.042$ & $2.73 \pm 0.063$ & $3.96 \pm 0.028$ & $0.29 \pm 0.007$ & $1.38 \pm 0.021$ & $1.80 \pm 0.191$ & $0.63 \pm 0.014$ \\
Stem & $0.97 \pm 0.049$ & $6.63 \pm 0.064$ & $1.34 \pm 0.007$ & $0.44 \pm 0.156$ & $0.29 \pm 0.057$ & $1.44 \pm 0.149$ & $0.82 \pm 0.092$ \\
\hline
\end{tabular}

Results are reported in mean \pm SD. Means with the same letter in a row are not significantly different $(P>.05)$

The above result shows that alkaloid and saponin were highest in the leaf $(4.08 \pm 0.028$ and $4.31 \pm 0.035 \mathrm{mg} / 100 \mathrm{mg})$ but lowest in the stem $(0.97 \pm 0.049$ and $1.34 \pm 0.007 \mathrm{mg} / 100 \mathrm{mg})$. Flavonoid, Phenol and Steroid were highest in the stem $(6.63 \pm 0.064,0.44 \pm 0.156$ and $0.82 \pm 0.092 \mathrm{mg} / 100 \mathrm{mg})$, while phenol and steroid were lowest in the root $(0.27 \pm 0.021$ and $0.54 \pm 0.021 \mathrm{mg} / 100 \mathrm{mg})$, flavonoid was lowest in the leaf $(1.49 \pm 0.001 \mathrm{mg} / 100 \mathrm{mg})$. Anthraquinone was highest in the root $(4.52 \pm 0.438 \mathrm{mg} / 100 \mathrm{mg})$ but lowest in the stem $(1.44 \pm 0.149 \mathrm{mg} / 100 \mathrm{mg})$.

Table 3: Proximate composition of different parts of Senna alata

\begin{tabular}{lllllll}
\hline Extract & $\begin{array}{l}\text { Moisture } \\
\text { content (\%) }\end{array}$ & Ash (\%) & Fat (\%) & $\begin{array}{l}\text { Crude } \\
\text { protein }(\%)\end{array}$ & $\begin{array}{l}\text { Crude fibre } \\
(\%)\end{array}$ & $\begin{array}{l}\text { Carbohydrate } \\
(\boldsymbol{\%})\end{array}$ \\
\hline Leaf & $15.71 \pm 0.431$ & $5.95 \pm 0.078$ & $9.67 \pm 0.191$ & $17.47 \pm 0.049$ & $17.42 \pm 0.714$ & $33.81 \pm 0.827$ \\
Root & $16.62 \pm 0.643$ & $4.87 \pm 0.191$ & $2.27 \pm 0.651$ & $13.24 \pm 0.134$ & $17.42 \pm 0.714$ & $50.52 \pm 1.945$ \\
Flower & $6.60 \pm 0.099$ & $5.27 \pm 0.085$ & $1.99 \pm 0.085$ & $9.79 \pm 0.064$ & $48.78 \pm 0.919$ & $27.55 \pm 0.919$ \\
Stem & $4.08 \pm 0.014$ & $4.08 \pm 0.014$ & $5.73 \pm 0.141$ & $14.85 \pm 0.021$ & $15.76 \pm 0.134$ & $55.67 \pm 0.021$ \\
\hline
\end{tabular}

Results are reported in mean \pm SD

The result of the percentage proximate composition shows that carbohydrate content was higher in the leaf (33.81 \pm 0.827$)$, root $(50.52 \pm 1.945)$ and stem $(55.67 \pm 0.021)$ of the plant, while the flower extract gave the high composition of crude fibre (48.78 \pm 0.919$)$. Fat content was found to be lowest in the root $(2.27 \pm 0.651)$ and flower $(1.99 \pm 0.085)$, Ash content was found to be lowest in the leaf $(5.95 \pm 0.078)$, while in the stem, both moisture content and ash $(4.08 \pm 0.014)$ were found to be lowest.

Table 4: Mineral composition of different parts of Senna alata 


\begin{tabular}{lllllll}
\hline Extract & $\mathbf{K}(\mathbf{m g} / \mathbf{1 0 0 m g})$ & $\begin{array}{l}\mathbf{Z n} \\
(\mathbf{m g} / \mathbf{1 0 0 m g})\end{array}$ & $\begin{array}{l}\mathbf{N a} \\
(\mathbf{m g} / \mathbf{1 0 0 m g})\end{array}$ & $\begin{array}{l}\mathbf{M g} \\
(\mathbf{m g} / \mathbf{1 0 0} \mathbf{m g})\end{array}$ & $\begin{array}{l}\text { Fe } \\
(\mathbf{m g} / \mathbf{1 0 0} \mathbf{m g})\end{array}$ & $\begin{array}{l}\text { Ca } \\
(\mathbf{m g} / \mathbf{1 0 0 m g})\end{array}$ \\
\hline Leaf & $779.01 \pm 0.276$ & $0.57 \pm 0.021$ & $0.55 \pm 0.028$ & $142.78 \pm 0.035$ & $42.36 \pm 0.014$ & $158.37 \pm 0.021$ \\
Root & $556.39 \pm 0.198$ & $0.96 \pm 0.042$ & $0.44 \pm 0.014$ & $89.95 \pm 0.028$ & $42.36 \pm 0.007$ & $116.17 \pm 0.028$ \\
Flower & $1121.85 \pm 0.141$ & $2.16 \pm 0.021$ & $0.16 \pm 0.0021$ & $148.21 \pm 0.042$ & $25.35 \pm 0.028$ & $63.33 \pm 0.042$ \\
Stem & $246.29 \pm 0.042$ & $2.35 \pm 0.035$ & $0.18 \pm 0.021$ & $55.61 \pm 0.156$ & $40.16 \pm 0.686$ & $124.14 \pm 0.014$ \\
\hline
\end{tabular}

Results are reported in mean \pm SD

The result of the mineral composition showed that potassium content was highest in all parts of Senna alata. The flower has the lowest content of iron $(25.35 \pm 0.028)$ and calcium $(63.33 \pm 0.042)$. The stem has the lowest magnesium content $(55.61 \pm 0.156)$. The flower has the lowest sodium content $(0.16 \pm 0.0021)$ while leaves have the lowest zinc content $(0.57 \pm 0.021)$.

\section{DISCUSSION AND CONCLUSION}

The medicinal value of a plant depends on the presence of certain chemical substances (secondary metabolites) which are involved in the production of different kinds of effects in the human body. Secondary metabolites in plants involved in the production of medicines are alkaloids, tannins, flavonoids, terpenes and phenolic compounds (Cowan, 1999). The presence of saponin in the leaf, root and flower suggests that the plant parts can be used to treat water supplies and wells contaminated with disease vectors. After treatment, the water is safe for human consumption (Hall and Walker, 2001). Saponins are also known to be immnune boosters (Sauvaire et al., 2006). They are also known to demonstrate anti-inflammatory, antihaemolytic, cholesterol-lowering and anti-cancer properties. Flavonoids are polyphenolic compounds that are ubiquitous in nature and are categorised according to their chemical structure into flavones, anthocyanidins, isoflavones, catechins, flavonols, chalcones and flavones. More than 4,000 flavonoids have been recognised, many of which occur in vegetables, fruits and beverages like tea, coffee and fruit drinks. These polyphenolic compounds have strong antioxidant activity. They also possess antifungal, antiviral, antibacterial, hepatoprotective, antithrombotic, and anticarcinogenic activities which are associated with their antioxidant and free radical scavenging properties (Okwu and Omodamiro, 2005). Anthraquinones have a laxative effect, anti-inflammatory, anti-cancer and anti-malarial properties (Sakulpanich and Gritsanapan, 2009). Some alkaloids are used as local anaesthetic and stimulants as cocaine (Okwu, 2004).

The flower extract revealed a high composition of crude fibre (48.78 \pm 0.919$)$ which is mainly needed to keep the digestive system healthy. It also contributes to stabilising glucose and

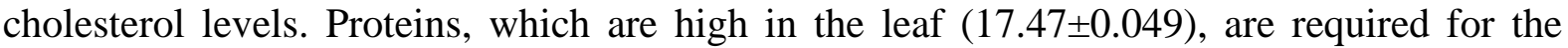
structure, function and regulation of the body tissues and organs (DHHS, 2017). The high levels of moisture content found in the leaf $(15.71 \pm 0.431)$ and root $(16.62 \pm 0.643)$ shows that it cannot be stored for long. Hence, demoisturizing increases their shelf life. This result is in cognizance with Esayas et al., (2011). The high content of ash found in the leaf (5.95 \pm 0.078$)$ indicated the availability of minerals in the sample. This result is correspondent with that of other researchers (Esayas et al., 2011). High levels of carbohydrates were found in all plant parts. However, these carbohydrates might not be nutritionally assessable since most of them are bound to remain undigested in the body (Gloria et al., 2010). 
The mineral analysis showed that $\mathrm{K}, \mathrm{Mg}, \mathrm{Fe}$ and $\mathrm{Ca}$ were present in appreciable quantity in all plant parts examined. K serves as an electrolyte. It influences the body's processes and it works in concert with $\mathrm{Na}$ to exert its effect. $\mathrm{Mg}$ helps maintain normal nerve and muscle function, supports a healthy immune system, keeps the heartbeat steady and helps strengthen the bone. Calcium is a mineral that must be constantly eaten to build bone and maintain blood levels of calcium (Rubin, 2008).

\section{REFERENCES}

Abdulwaliyu, I.; Arekemase, S. O.; Bala, S.; Ibraheem, A. S.; Dakare, A. M.; Sangodare, R. and Gero, M. (2013). Nutritional properties of Senna alata Linn leaf and flower. International Journal of Modern Biology and Medicine. 4(1): 1-11

Bemiller, N. J. (2003). Carbohydrate analysis. In: SS. Nielson (Edn.) Food Analysis. $3^{\text {rd }}$ edition, Kluwer Academic/Plenum Publishers, New York. Pp. 143-174

Boham, B. A. and Kocopai, A. R. (1994). Flavonoids and condensed Tannins from Leaves of Hawaiian Vaccinium vaticulatum and V. Calycinium. Pacific Science. 48: 458-463

Bradley, R. Y. (2003). Moisture and Total Solid Analysis. In: SS. Nielson (Edn.) Food Analysis. $3^{\text {rd }}$ edition, Kluwer Academic/Plenum Publishers, New York. Pp. 83-85

Burkill, H. M. (2002). The Useful Plants in West Tropical Africa. $2^{\text {nd }}$ edition. Addenda Royal Botanic Gardens, Kew, Richmond. The United Kingdom. Pp 689

Capenter, C. E. and Hendricks, D. G. (2003). Mineral analysis. In: SS. Nielson (Edn.) Food Analysis. $3^{\text {rd }}$ edition, Kluwer Academic/Plenum Publishers, New York. Pp. 195

Chang, S. K. C. (2003). Protein analysis. In: SS. Nielson (Edn.) Food Analysis. $3^{\text {rd }}$ edition, Kluwer Academic/Plenum Publishers, New York. Pp. 83-85p

Cowan, M. M. (1999). Plant products as antimicrobial agents. Clinical Microbiology Reviews 12: $564-582$

Department of Health and Human Services (2017). What are proteins and what do they do? Accessed $12^{\text {th }}$ June 2017, from www.genetics/home/reference.html

Esayas. K.; Shimelis, A.; Ashebir, F.; Tilahun, B. and Gulelat, D. (2011). Proximate composition, mineral content, and antimicrobial content of some Capsicum annum varieties grown in Ethiopia. Journal of Korean Society of Food Science and Nutrition. 37(8): 1084-1089

Gloria, A.; Oyedola, B.; Adenika, T. and Anthony, J. (2010). Comparative analysis of the chemical composition of three species-Allium sativum L., Zingiber officinale Rosc. and Capsicum frutescens L. commonly consumed in Nigeria. African Journal of Biotechnology 9(41): 6927-6931

Hall, J. B. and Walker, D. H. (2001). Balanites, aegyptiaca Del-A monograph. School of Agricultural and Forest Science, University of Wales, Banger, Uk

Harbers, H. L. and Nielson, S. S. (2003). Ash analysis. In: SS. Nielson (Edn.) Food Analysis. $3^{\text {rd }}$ edition, Kluwer Academic/Plenum Publishers, New York. Pp. 103-112

Harborne, J. B. (1973). Textbook of phytochemical methods. Chapman and Hall Ltd., London. Pp 49-188

James, C. J. (1995). The analytical chemistry of foods. Chapman and Hall Press, New York, Pp 86

Jude, E. O.; Bassey, A.; Grace, E. and Lucky, L. N. (2007). Evaluation of the antiplasmodial activity of ethanolic leaf extract of Lasianthera Africana. International Journal of Pharmacology 1: 30-33 
Makinde, A. A.; Igoli, G. T. A.; Ama, L.; Shaibu, S. J. and Garaba, A. (2007). Antimicrobial activity of Cassia alata. African Journal of Biotechnology 6: (1509-1510)

Min, D. B. and Boff, J. M. (2003). Crude Fat Analysis. In: SS. Nielson (Edn.) Food Analysis. $3^{\text {rd }}$ edition, Kluwer Academic/Plenum Publishers, New York. Pp. 113-130

Ogunti, E. O. and Elujoba, A. A. (2009). The laxative activity of Cassia alata Linn. Fitoterapia 64:325-328

Okeke, C. U. and Elekwa, I. (2003). Proximate and preliminary phytochemical analysis of avocado pear (Persea gratissima) Gaertn. Nigerian Journal of Botany 19: 156-162

Okwu, D. E. (2004). Phytochemicals and vitamin content of indigenous species of southeastern Nigeria. Journal of Sustaining Agricultural Environment 6: 30-37

Okwu, D. E. and Omodamiro, O. D. (2005). Effects of hexane extract and phytochemical content of Xylopia Ethiopia and Ocimum gratissimum on the uterus of guinea pig. Biological Research 3: 40-44

Onwuka, G. F (2005). Food analysis and instrumentation theory and practice. Naphthali print, a division of A. A. support Nigeria Ltd

Pearson, D. (1976). Chemical analysis of food. Church-hill Livingstone Edinburgh, UK. Pp 103-110

Rubin, A. L. (2018). What are the functions of calcium in the body? https://www.dummies.com/health/nutrition/vitamins/funnctionsofcalciuminthebody accessed Nov. 2019

Sakulpanich, A. and Gritsanapan, W. (2009). Determination of anthraquinones glycoside content in Cassa fistula leaf extracts for an alternative source of the laxative drug. International Journal of Biomedical and Pharmaceutical Science 3:42-45

Sauvaire, Y.; Baissac, Y.; Leconte, E.; Petit, P. and Ribes, G. (1996). Steroid saponins from fenugreek and some of their biological properties. Advances in Experimental medicine and biology 405:37-38

Somchit, M. N.; Reezal, N. I. E. and Mutalib, A. R. (2003). In vitro antimicrobial activity of ethanol and water extract of Cassia alata. Journal of Ethnopharmacology 84(1): 1-4

Usunobun, U. and Ewaen, M. E. (2014). Phytochemical analysis, proximate and mineral composition and in vitro antioxidant activities in Telferai occidentalis aqueous extract. Journal of Basic and Applied Sciences 1(1): 74-87

Yakubu, M. T.; Adesina, A. O.; Oladiji, A. T.; Akanji, M. A.; Oloyede, O. B.; Jimoh, G. A.; Olatinwo, A. W. O. and Afolayan, A. J. (2010). Abortifacient potentials of aqueous extract of Senna alata Linn leaves in the rat. International Journal of Reproduction, Contraception, Obstetrics and Gynaecology 21: 163-177 